\title{
GEOTHERMAL INVESTIGATIONS IN BRAZIL
}

\author{
ICARO VITORELLO*, VALIYA M. HAMZA**, HENRY N. POLLACK* \\ and RUTENIO L.C. ARAUJO**
}

ABSTRACT A geothermal project was initiated in 1975 to delineate the regional distribution of geothermal gradients and terrestrial heat flow and, at the same time, to provide information related to such problems as underground mine ventilation, and movements of subsurface water. Borehole and mine temperature measurements were made with a high sensitivity electrical resistance thermometer (thermistor), attached by cable to a Wheatstone resistance bridge. Temperature disturbances due to drilling operations, variation in surface temperature, underground air and water movements, topographic relief, and complex geological structures are illustrated and evaluated.

Temperature gradients are reported for 85 boreholes and two underground mines, located in 19 different geographic sites of the Precambrian shield of Brazil, the Phanerozoic Paraná Basin, and the Paleocene alkaline intrusion of Poços de Caldas. Individual gradients range from $6^{\circ} \mathrm{C} / \mathrm{km}$, in the early Proterozoic quartzites of Jacobina (Bahia), to $42^{\circ} \mathrm{C} / \mathrm{km}$ obtained in the southern portion of the Paraná Basin (Butiá, R.G.S.).

There is an increasing gradient pattern for decreasing tectonic age, from the low average gradients of $11-12^{\circ} \mathrm{C} / \mathrm{km}$ for the Transamazonic (2600-1800 Ma) and Espinhaço (1800$1300 \mathrm{Ma}$ ) folding, $16^{\circ} \mathrm{C} / \mathrm{km}$ for the Brazilian folding $(900-550 \mathrm{Ma})$, to the strikingly higher $28^{\circ} \mathrm{C} / \mathrm{km}$ for the sediments of the Parana Basin, and $30^{\circ} \mathrm{C} / \mathrm{km}$ for the magmatism of Poços de Caldas.

Heat flow determinations will be made at each site following the measurements of the thermal conductivity of borehole cores.

RESUMO Um projeto de pesquisa geotérmica no Brasil foi iniciado em 1975, para delinear a distribuição regional dos gradientes geotérmicos e o fluxo térmico terrestre, e tam. bém fornecer informaçōes relacionadas a problemas de ventilação de minas subterrâneas e movimcntos de água no subsolo. As temperaturas em furos e minas foram obtidas com um termômetro de resistência elétrica (termistor) de alta sensitividade, ligado por cabo elétrico a uma ponte de resistência tipo Wheatstone. Perturbações térmicas, ocasionadas pela atividade de perfuração, por variação da temperatura na superfície, por movimentos subterrâneos de ar e água, por relevo topográfico e por estruturas geológicas complexas, são apresentadas e analisadas.

Gradientes de temperatura são apresentados para 85 furos de superfície e para duas minas subterrâneas, localizados em 19 regiões geográficas distintas no Escudo Precambriano do Brasil, na Bacia Fanerozóica do Paraná, e na intrusão de rochas alcalinas de Poços de Caldas, durante o Paleoceno. Os gradientes individuais variam de $6^{\circ} \mathrm{C} / \mathrm{km}$ encontrados nos quartzitos do Proterozóico Inferior de Jacobina (Bahia), a $42^{\circ} \mathrm{C} / \mathrm{km}$ obtido na parte meridional da bacia do Paraná (Butiá, R.G.S.).

Há um aumento de gradiente térmico com a diminuição da idade tectônica, dos baixos valores médios de $11-12^{\circ} \mathrm{C} / \mathrm{km}$ dos dobramentos transamazônicos (2600-1800 Ma) e Espi-

* Department of Geology \& Mineralogy, The University of Michigan - Ann Arbor - Michigan 48109 - USA.

** Departamento de Geofísica, Instituto Astronômico e Geofísico, Universidade de São Paulo, C. Postal $30.627-01000$ - S. Paulo - Brasil. 
nhaço (1800-1300 Ma), aos bem mais elevados $28^{\circ} \mathrm{C} / \mathrm{km}$ dos sedimentos da bacia do Paraná e $30^{\circ} \mathrm{C} / \mathrm{km}$ do complexo vulcânico de Poços de Caldas.

As determinações do fluxo térmico serão feitas para cada local, depois que as medidas de condutividade térmica nos testemunhos dos furos forem efetuadas.

INTRODUCTION Many important geological procèsses are manifestations of the earth's internal heat, as evidenced by the global plate motions with associated earthquake and volcanic activity, magma generation, and several other phenomena. The heat controlling these processes is transported by thermal conduction and convection through the earth, ultimately being radiated into space when reaching the surface.

The amount of heat that flows outward by conduction through the crust can be measured in boreholes and underground mines; its magnitude is given as the product of the temperature gradient and the thermal conductivity of the rocks, through which the heat is being conducted. The temperature gradient is the rate of increase of temperature with depth obtained from field temperature measurements in the ground, well below the surface, whereas conductivity is usually determined by laboratory measurements of representative rock samples cored from the boreholes.

An analysis of these measurements gives insight into the temperature distribution in the crust and upper mantle, which is of fundamental importance in deducing the geologic and tectonic evolution of an area. On a global scale the surface.distribution of heat flow is not uniform either in continents or oceans, yet it is closely related to the tectonic character of an area (see Chapman and Pollack, 1975). In general, the surface heat flow decays from high values in more recent orogenic regions to the very low values that characterize the stable Precambrian shields. It has been suggested by several authors (Polyak and Smirnov, 1968; Hamza and Verma, 1969; Sclater and Francheteau, 1970), that the heat flow of an area is related to its tectonic age, decreasing from a younger to an older province. This is also reflected in the association between low surface heat flow, thick lithosphere, and geological stability on one hand, and high surface heat flow, thin lithosphere, and tectonic activity on the other hand (Chapman and Pollack, 1975). The geotherms (temperature-depth profiles) of tectonically active regions, reach temperature of incipient melting of deep-seated rocks at shallower depths than geotherms under stable regions do. These considerations indicate that the surface heat flow is a fundamental parameter to all temperature dependent geodynamic models, including the earth's thermal history and plate tectonics.

Geothermal measurements also bear upon several aspects of more immediate economic significance. Since heat, by its effect upon the health and productivity of the miners, is one of the factors that determines the depth from which ore can be economically extracted, the rate of increase of temperature with depth is by itself of importance in the planning of ventilation systems in underground mines. For this reason, thermal gradients were obtained in several regions of Brazil where underground mining is currently in active operation or undergoing development: Currais Novos (R. G. N. - tungsten); Caraíba (Bahia - copper); Jacobina (Bahia gold); Morro Agudo (M. G. - lead and zinc); Mina Grande and Raposos in Nova Lima (M. G. - gold); and Poços de Caldias (M. G. - radioactive materials). 
Thermal logging down deep boreholes can be used in the identification of major rock formations of different thermal conductivities. For instance, the low thermal conductivity of coal seams and associated carbon rich shales, produce a characteristic high temperature gradient that could be useful in the search for and assessment of coal beds in the Paleozoic basins of Brazil. Beck (1976) has described the potential use of temperature gradient profiles an stratigraphic correlation; comparing them with electrical resistivity logs. In coal-bearing formations, there is a positive correlation between those two logs, whereas in other lithologic units they show ne. gative correlation.

Furthermore, geothermal studies can be conducted in the search of economically important heat-generating deposits either at great depth or close to the surface. The possibility of making rough estimates of the size of bodies, rich in radioactive elements by delineating heat flow azomalies, is currently under study in the region of Poços de Caldas.

Sulfide deposits can also give rise to characteristic geothermal anomalies, due to the liberation of large amounts of heat during oxidation of pyrite into limonite (Lovering, 1948). Analysis of a temperature survey conducted in the valley of Curaça River, Bahia, where copper mineralization is associated with mafic and ultramafic rocks, is currently underway.

Present-day geothermal power plants in several countries use natural steam and very hot water from Late Cenozoic volcanic sources. While in geologically older regions such as Brazil such phenomena are less likely, geothermal survey can give specific geologic information in the detection of underground supplies of hot and cold water for industrial and agricultural consumption. Current temperature data collection in aquifers of the state of São Paulo may, in particular, turn out to be useful in the determination of their flow characteristics.

PREVIOUS GEOTHERMAL INVESTIGATIONS IN BRAZIL Although several thousand heat flow determinations have been made at the surface of the earth in the past two decades, no major geothermal work has been undertaken in the past in Brazil.

A project initiated by Uyeda and Watanabe (1970) in countries of South America, advanced only to the stage of estimating geothermal gradients for a limited number of sites, including 15 gradients obtained from bottom-hole temperature of petroleum boreholes in 5 sedimentary basins of Brazil. These gradients are usually estimated from the difference between one or two bottom-hole temperature measurements taken during drilling, and the mean annual surface temperature.

Meister (1973) has also assembled geothermal gradient data from over 500 petroleum boreholes in 15 sedimentary basins of Brazil. A compilation of these results (see Fig. 1) is a very useful first look at the thermal state of the Brazilian sedimentary basins. Average gradients in Mesozoic coastal grabens, associated with the breakup of the Gondwana supercontinent, are the highest in Brazil, ranging from $19-25^{\circ} \mathrm{C}$ / $\mathrm{km}$. The older Paleozoic intracratonic basins (Amazonas, Parnaíba and Paraná), reveal an average range of $17-21^{\circ} \mathrm{C} / \mathrm{km}$. As will be seen, these older intracratonic basins are probably better indicators of shield geothermics than are the marginal basins.

In addition, an average gradient of $18.9 \pm 2.9$ (SD) ${ }^{\circ} \mathrm{C} / \mathrm{km}$ was also estimated from several bottom-hole temperatures in six oil fields of the Recôncavo Basin, in 


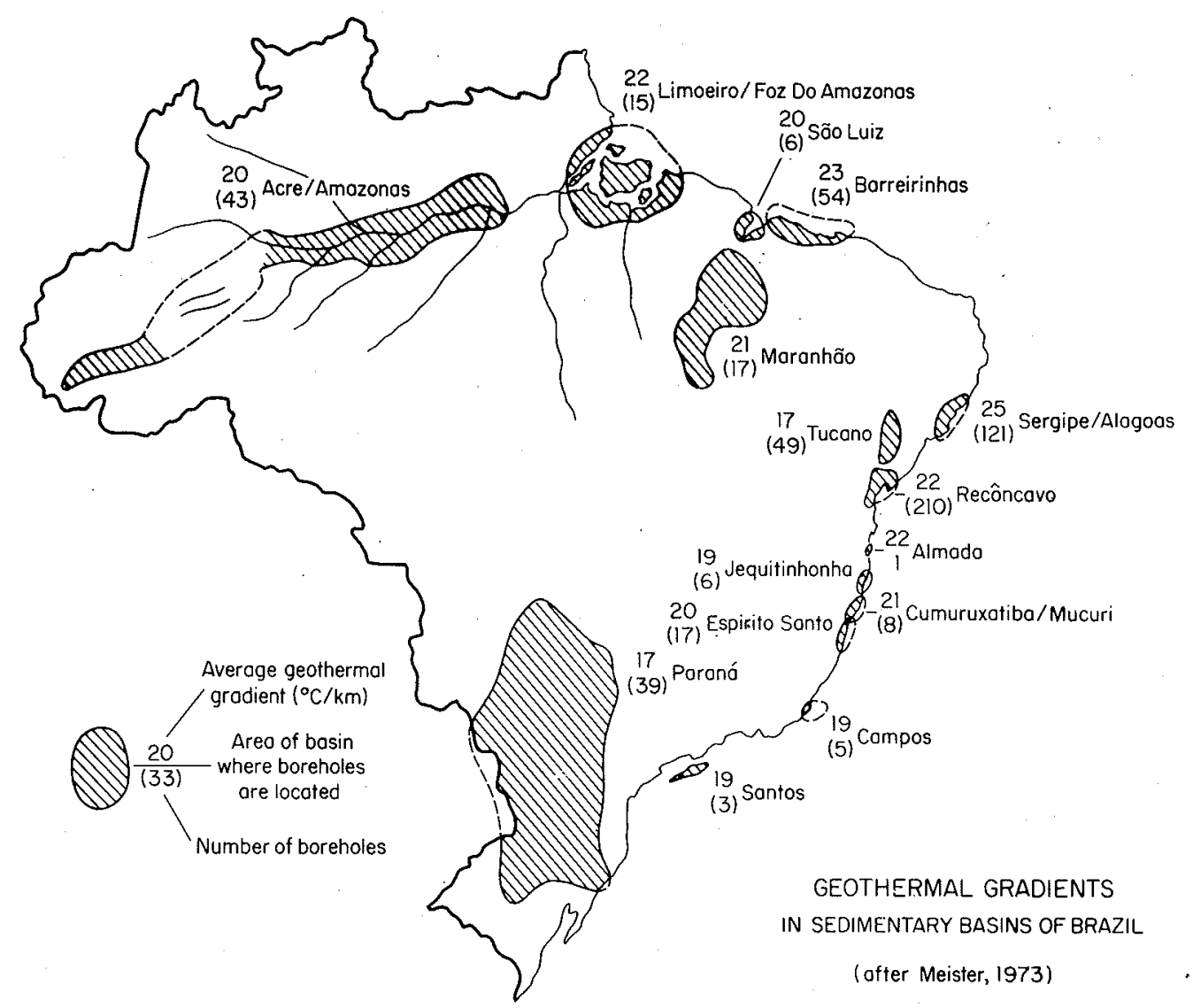

Figure 1 - Average geothermal gradients in sedimentary basins of Brazil, from petroleum bottom-hole temperatures, reported by Meister (1973)

the northeastern coast of Brazil, by Carvalho and Vacquier (1977). They calculated the thermal conductivities from available core samples and electric logs and reported an estimated heat flow value of $46.0 \pm 6.3(\mathrm{SD})$ milliwatts/meter ${ }^{2}$ (or $1.10 \pm 0.15$ (SD) $\left.\mu \mathrm{cal} / \mathrm{cm}^{2} \mathrm{~s}\right)$.

CURRENT GEOTHERMAL INVESTIGATIONS A heat flow measurement project, aiming to greatly expand the amount and distribution of geothermal information in Brazil, was initiated with the cooperation of several mining and drilling companies, as well as state and national government agencies of Brazil. In a little more than one year of field work, August 1975 to August 1976, temperature survey attempts in several hundred boreholes yielded more than 80 surface and underground geothermal gradients. The boreholes are grouped into 19 sites having from 1 to 19 boreholes each, according to geologic and geographic setting (Fig. 2). A summary of the temperature survey data is given in Table $I$ in which the sites are ordered by latitude. Some sites have several boreholes separated by as much as $30 \mathrm{~km}$, while others consist of only a single borehole. Consequently, we have indicated only 


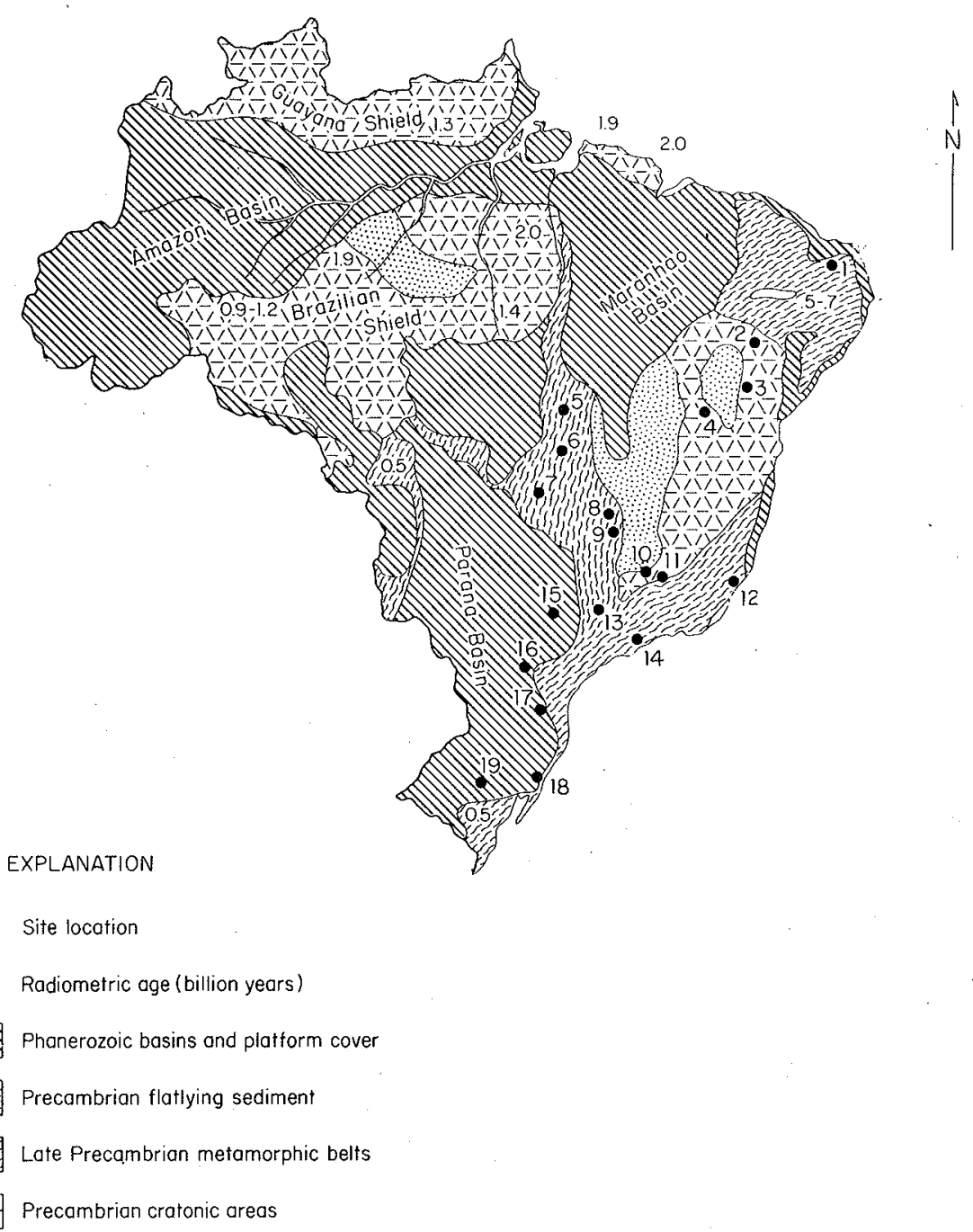

Figure 2 - Generalized tectonic map of Brazil showing sites of current geothermal investigations. The site numbers correspond to the locations listed in Table I

approximate coordinates, average elevation, and listed only the most representative rock type. The given site ages correspond to the tectonic age range obtained from the Tectonic Map of Brazil (1971). Paraná Basin sites show ages of the outcropping formations.

Unfortunately, a small geographic and geologic bias towards mineralized regions along the eastern portion of Brazil could not be avoided, as success in finding available boreholes is related to the intensity of mining exploration. Experimental techniques and typical examples of temperature gradients of each site will be discussed in the following sections; heat flow results will be available in the future after the determination of thermal coductivity values. 
Table I - Summary of temperature gradients data

\begin{tabular}{|c|c|c|c|c|c|c|c|c|}
\hline 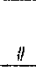 & LOCATYON (STATE) & $\begin{array}{l}\text { SOUTH } \\
\text { LAT. }\end{array}$ & $\begin{array}{l}\text { WEST } \\
\text { LONG. }\end{array}$ & $\begin{array}{l}\text { TECTONIC } \\
\text { AGE (M.Y.) }\end{array}$ & ROCK TYPE & $\begin{array}{l}\text { MEAN SITE ELEV. } \\
\text { (Neters above } \\
\text { sea level) }\end{array}$ & $\begin{array}{l}\text { TEMPELATURE } \\
\text { GRDIENTS } \\
\left({ }^{\circ} \mathrm{c} / \mathrm{km}\right) \\
\end{array}$ & $N *$ \\
\hline 1 & Currais Novos (Bahia) & $6^{\circ} 20^{\prime}$ & $36^{\circ} 35^{\prime}$ & $900-550$ & Paragneisses & 300 & $19-25$ & 5 \\
\hline 2 & $\begin{array}{l}\text { Caraíba-Pofo de Fora } \\
\text { (Bahia) }\end{array}$ & $10^{\circ} 20^{\prime}$ & $40^{\circ} 10^{\prime}$ & $2600-1800$ & $\begin{array}{l}\text { Mafics and } \\
\text { ultramafics }\end{array}$ & 455 & $12-21$ & 19 \\
\hline 3 & Jacobina (Bahia) & $11^{\circ} 15^{\prime}$ & $40^{\circ} 30^{\prime}$ & $2600-1800$ & $\begin{array}{l}\text { Meta Sedimentary } \\
\text { (Quartzites) }\end{array}$ & $500-1200$ & $6-10$ & 11 \\
\hline 4 & Arraial (Bahin) & $12^{\circ} 32^{\prime}$ & $42^{\circ} 50^{\prime}$ & $2600-1800$ & Blotite Schist & 600 & $11.5-1.3$ & 2 \\
\hline 5 & Cana Brava (Goiás) & $13^{\circ} 30^{\prime}$ & $48^{\circ} 15^{\prime}$ & $900-550$ & Serpentinites & 400 & $16-18^{\circ}$ & 3 \\
\hline 6 & Nique1ândia (Goiás) & $14^{\circ} 13^{\prime}$ & $48^{\circ} 18^{\prime}$ & $900-550$ & $\begin{array}{l}\text { Ultra basics } \\
\text { (Gabbros) }\end{array}$ & 570 & $17-21$ & 2 \\
\hline 7 & Americano (Goiás) & $16^{\circ} 25^{\circ}$ & $50^{\circ} 00^{\prime}$ & $900-550$ & $\begin{array}{l}\text { Mafics and } \\
\text { ultramafics }\end{array}$ & 240 & $12-16$ & 2 \\
\hline 8 & $\begin{array}{l}\text { Norro Agudo } \\
\text { (Minas Gerais) }\end{array}$ & $17^{\circ} 30^{\prime}$ & $46^{\circ} 50^{\prime}$ & $900-550$ & Dolomites & 580 & $10-13$ & 5 \\
\hline 9 & $\begin{array}{l}\text { Vazante } \\
\text { (Minas Gerals) }\end{array}$ & $18^{\circ} 00^{\prime}$ & $46^{\circ} 45^{\prime}$ & $900-550$ & Dolomites & 750 & $11-12$ & 1 \\
\hline 10 & $\begin{array}{l}\text { Kova Lima } \\
\text { (Minas Gerats) }\end{array}$ & $20^{\circ} 00^{\prime}$ & $43^{\circ} 50^{\prime}$ & $1800-1300$ & Schists & $750-800$ & $14-16$ & $i^{*} \div$ \\
\hline 1 & $\begin{array}{l}\text { Bico de Pedra } \\
\text { (Minas Gerais) }\end{array}$ & $20^{\circ} 26^{\prime}$ & $43^{\circ} 36^{\prime}$ & $1800-1300$ & Meta Sedimentary & 1410 & $7-8$ & 2 \\
\hline 12 & $\begin{array}{l}\text { Cachoetra do } \\
\text { Itapemirim. } \\
\text { (Espírito Santo) }\end{array}$ & $20^{\circ} 51^{\prime}$ & $41^{\circ} 06^{\prime}$ & $900-550$ & Dolomites & 327 & $11-12$ & 1 \\
\hline 13 & $\begin{array}{l}\text { Pofos de caldas } \\
\text { (Minas Gerais) }\end{array}$ & $21^{\circ} 55^{\prime}$ & $46^{\circ} 25^{\prime}$ & $80-60$ & $\begin{array}{l}\text { Alkaline } \\
\text { Intrusion }\end{array}$ & $1100-1200$ & $25-35$ & 9 \\
\hline 14 & São Paulo (S,P.) & $23^{\circ} 36^{\prime}$ & $46^{\circ} 34^{\prime}$ & $900-550$ & Granites & 770 & $21-23$ & 2 \\
\hline 15. & State of São Paulo & $22^{\circ} 00^{\prime}$ & $48^{\circ} 30^{\prime}$ & Cretaceous & Basilt & $400-600$ & $18-22$ & 4 \\
\hline 16 & $\begin{array}{l}\text { Figueira } \\
\text { (Paraná) }\end{array}$ & $24^{\circ} 00^{\prime}$ & $50^{\circ} 25^{\prime}$ & $\begin{array}{l}\text { Lower } \\
\text { Devonian }\end{array}$ & Sedimentary & $400-800$ & $22-28$ & 5 \\
\hline 17 & $\begin{array}{l}\text { Papanduva-Taió } \\
\text { (Sta: Catarina) }\end{array}$ & $26^{\circ} 23^{\prime}$ & $50^{\circ} 08^{\prime}$ & $\begin{array}{l}\text { Upper Car- } \\
\text { boniferous }\end{array}$ & $\begin{array}{l}\text { Sedimentary } \\
\text { (Sandstones \& } \\
\text { Limestones) }\end{array}$ & $300-700$ & $23-28$ & 3 \\
\hline 18 & $\begin{array}{l}\text { Araranguá-Lauro } \\
\text { Muller (Sta. } \\
\text { Catarina) }\end{array}$ & $28^{\circ} 40^{\prime}$ & $49^{\circ} 30^{\circ}$ & $\begin{array}{l}\text { Lower } \\
\text { Permian }\end{array}$ & $\begin{array}{l}\text { Sedimentary } \\
\text { Shales \& } \\
\text { Limestones }\end{array}$ & $0-250$ & $26-40$ & 2 \\
\hline 19 & $\begin{array}{l}\text { Butid-R. Pardo } \\
(R, G, \text { Sul })\end{array}$ & $30^{\circ} 05^{\prime}$ & $52^{\circ} 30^{\prime}$ & $\begin{array}{l}\text { Upper } \\
\text { Triassic }\end{array}$ & $\begin{array}{l}\text { Sedimentary } \\
\text { Shales \& } \\
\text { Limestones }\end{array}$ & $40-70$ & $30-42$ & 8 \\
\hline
\end{tabular}

It SITE NLMBER

* $N=$ number of boreholes that yielded reasonable geothermal gradients

: $:$ : $=$ Underground mine 
TEMPERATURE MEASUREMENTS Equipment The temperature sensor used is an electrical semiconductor resistance thermometer, or thermistor. Of the several sensors that have been in use, thermistors are frequently chosen because of their sensitivity, resistance to shocks, and wide temperature range. Since their resistance decreases rapidly with temperature, their thermal sensitivity is given by a variable coefficient of resistance. The thermistors used have coefficients of $100 \Omega /{ }^{\circ} \mathrm{C}$ for temperatures around $60^{\circ} \mathrm{C}$, and of $800 \Omega /{ }^{\circ} \mathrm{C}$ for temperatures around $10^{\circ} \mathrm{C}$. Consequently, we can detect temperature changes in the order of $.001^{\circ} \mathrm{C}$ in low ambient temperatures and of $.01^{\circ} \mathrm{C}$ in high ambient temperatures. Nevertheless, the absolute accuracy is not better than $0.05^{\circ} \mathrm{C}$, due principally to calibration and measurements errors. It should also be pointed out that the measured value represents the temperature of the fluid filling the hole, which might be somewhat different from the temperature of the surrounding rock. Each thermistor was calibrated against calibrated precision laboratory thermometers and for field work it was mounted into a waterproof cylindrical housing and connected to a Wheatstone resistance bridge by electrical cable (Fig. 3). For a field measurement, the probe is in: troduced into the borehole to the desired depth, and its resistance is measured on the bridge at the surface.

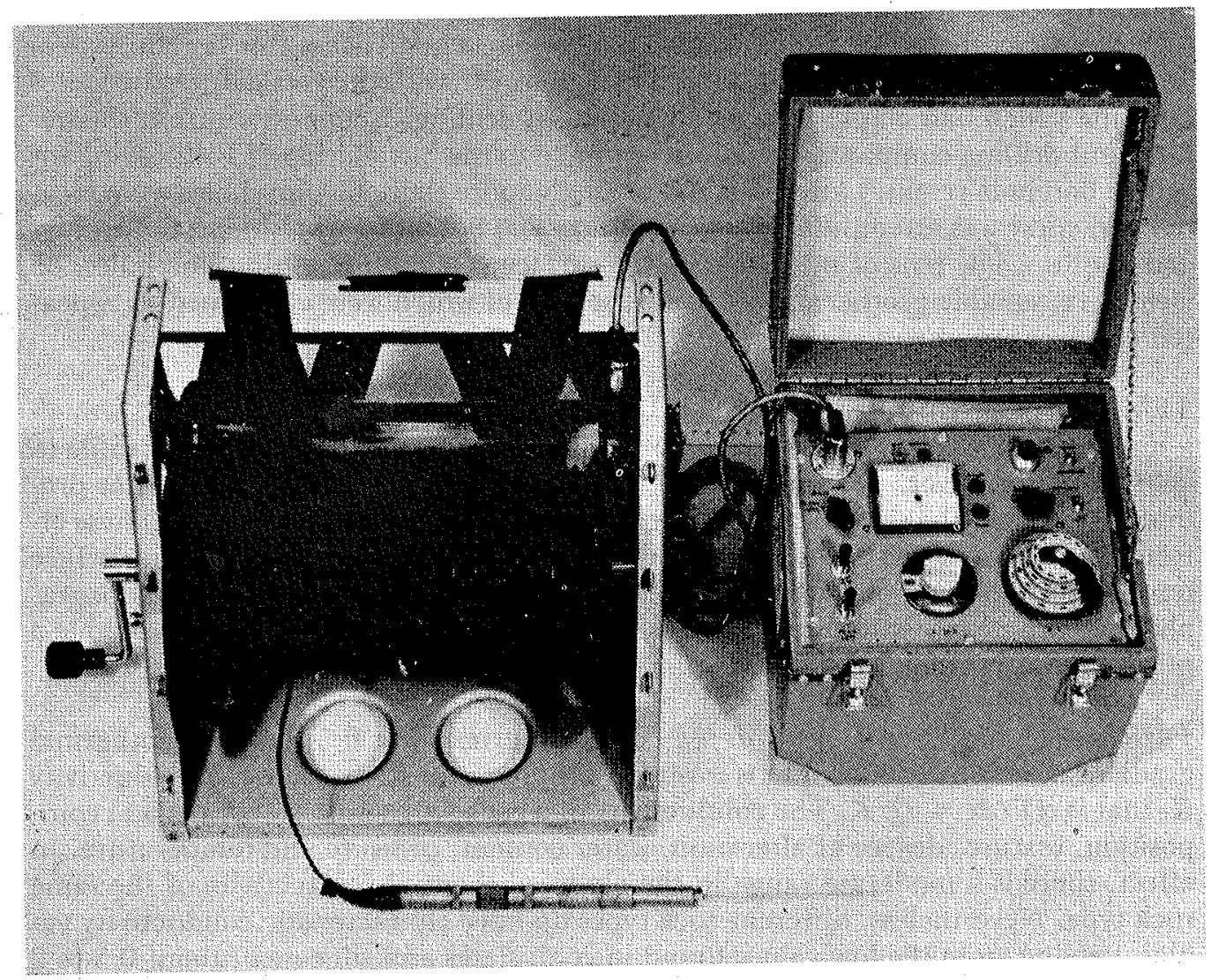

Figure 3 - Portable geothermal measuring equipment showing the probe, winch with 600 meters of cable and the Wheatstone resistance bridge. The gear weighs only $30 \mathrm{~kg}$ 
What makes a satisfactory hole? Continental heat flow measurements are generally performed in drill holes, which were originally bored for other purposes. Best results are obtained in vertical boreholes of 200 meters or more, with no water circulation, several weeks after completion of drilling. The daily and annual variations of atmospheric temperatures generally penetrate only a few centimeters and meters, respectively, into the ground. Ground water infiltration, however, can affect the rock temperature at greater depth. In inclined boreholes, the lowering of the sensor is hindered by wall detritus, rock cavities, and diameter reductions. Settled drilling mud will also prevent a probe's free descent through a borehole, unless the hole has been flushed following completion.

The drilling operation usually disturbs the wall rock temperature to the extent that a time-lapse of several days is required for the rock temperature to return to its undisturbed value. Since the metal casings used for drilling are extracted from the borehole immediately at the completion of drilling, the borehole opening commonly becomes obstructed by falling wall detritus and cave-ins. To preserve the opening for future accessibility while the temperature disturbance due to drilling decays, the upper part of the boreholes can be supported by inexpensive PVC (poly-vinyl chloride) casing.

Field procedures In this project the adopted practice was to make temperature measurements at regular depth intervals of 10 meters in all accessible boreholes deeper than 100 meters and inclination smaller than $45^{\circ}$ with the vertical, regardless of the time which had elapsed since completion of drilling. Cooperation from the mining and drilling companies was often obtained in the installation of PVC casing for future borehole re-entry attempts. Accordingly more than 300 boreholes were located and entry was attempted, however, almost 200 boreholes were found to be plugged within a few tens of meters from the surface. Of the remaining boreholes, 85 yielded reasonable geothermal gradients, several of which were confirmed by repeated temperature measurements.

TEMPERATURE VERSUS DEPTH PROFILES A constant heat flow through a uniform medium is characterized by a linear temperature versus depth profile (a geotherm). However, these are several natural and a few artificial effects that produce changes in the slope of the profile at various depths in the borehole. These effects include variation of lithology and hence of conductivity with depth, surface temperature fluctuation, subsurface heat sources and sinks, structural and topographic perturbations, and several others. These factors must be evaluated to enable a proper interpretation of the profile.

Variation of conductivity with depth For a given heat flow $Q$, the geothermal gradient $d T / d z$ in equilibrium is inversely proportional to the thermal conductivity $K$, that is $d T / d z=Q / K$. The conductivity of a rock varies with mineralogical composition, texture, degree of alteration, water content, pressure and temperature. In effect, there is a moderate range in the observed thermal conductivity of the same rock type. Nevertheless, different rock types do have characteristic conductivity values; varying from the low values found in coal, slates and siltstones (about 0.5 to 2 watts $/$ meter $/{ }^{\circ} \mathrm{C}$ ) to the high values found in quartzites, gneisses, dunites, dolomites, and halite (about 5 to $8 \mathrm{~W} / \mathrm{m} /{ }^{\circ} \mathrm{C}$ ). 
Very often, the changes in the slope of a temperature profile can be correlated to the lithological variation with depth, as in Fig. 4, where the thermal logging was done in a borehole penetrating sediments of Passa-Dois group, near Rio Pardo (R.G.S.). The temperature values at ten meters intervals are plotted versus depth to enable correlation with the borehole lithology. In this example, each formation presents characteristic gradient ranges and a few gradational values at transition zones. The reddish sandstones of the Rio do Rasto formation are characterized by low gradients, $\left(8-1,5^{\circ} \mathrm{C} / \mathrm{km}\right)$, whereas the Estrada Nova and Irati formations, composed mostly of grayish silty shales, have relatively higher values $\left(40-45^{\circ} \mathrm{C} / \mathrm{km}\right)$.

In the Palermo formation the gradients tend to decrease as the sedimentary layers go from silty shales at the top to sandy shales and siltites toward the bottom.

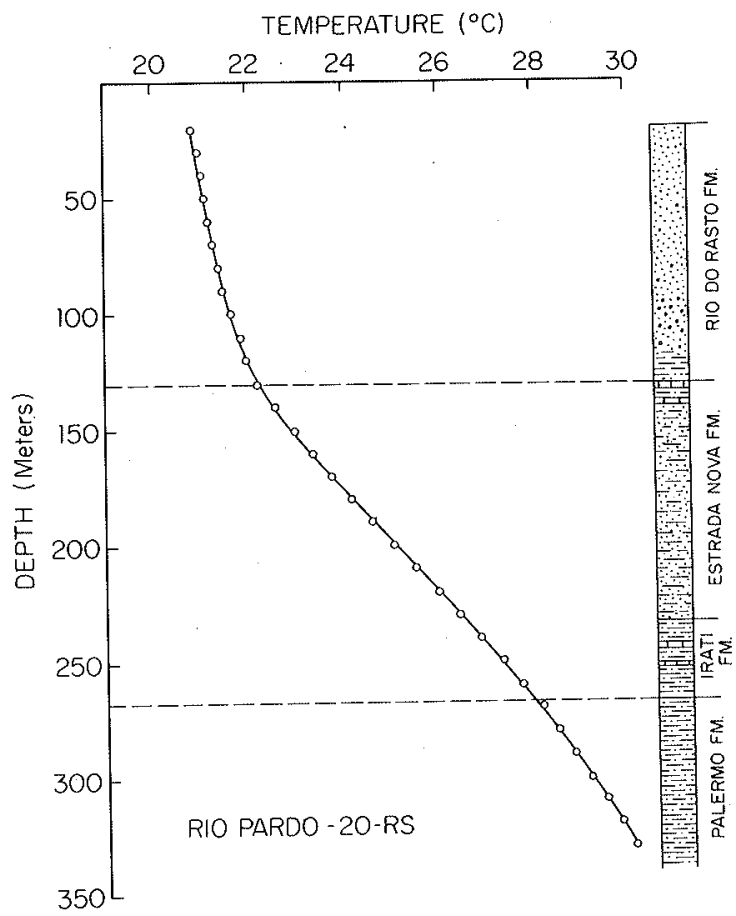

Figure 4 - Correlation between gradient and lithological variations with depth for borehole 20-RS, from Rio Pardo (R.G.S.)

Surface temperature fluctuation The temperature at the surface of the earth is related to the variations of the surrounding atmospheric temperature caused by the solar radiation, and consequently varies strongly with the local conditions. Below a depth of a few meters, which is the penetration zone of the short-term daily and seasonal surface variations, there is ordinarily a steady increase of temperature with depth, and any inflection in the temperature-depth profile is caused by longer-term climatic and physiographic changes. Uplift and erosion tend to lower the surface temperature and increase the temperature gradient, whereas subsidence and sedimentation tend to lower the temperature gradient. In any case, the original surface perturbation progresses downward with a diminishing intensity, eventually dying off at a depth dependent upon the duration of the disturbance. Below this depth, the temperature is controlled by the heat flowing from the earth's interior. 
No major climatic change has occurred in Brazil in the last few centuries. However, small regional surface temperature changes are very common, especially the ones caused by the removal of forest cover. The diagram in Fig. 5 exemplifies the possible surface warming due to the development of various open pit mines at the surface and forest removal in the last $100-200$ years. In this case, a reliable geothermal gradient was detected below 100 meters depth and its extrapolation to the surface (dashed line) revealed a previous mean annual surface temperature below $21^{\circ} \mathrm{C}$.

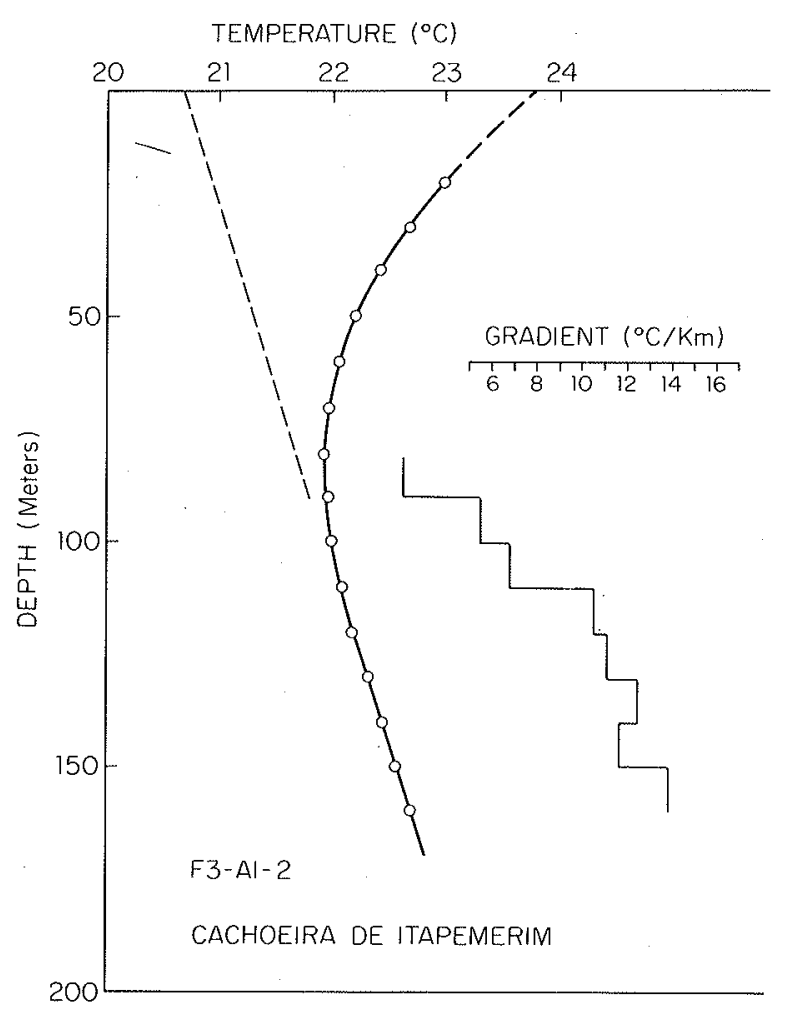

Figure 5 - Temperature-depth profile for borehole in Cachoeira de Itapemirim (E.S.) showing considerable departure from linearity near the surface, indicating a surface warming of several degrees

Subsurface heat sources and sinks Geotherms are usually disturbed by magmatic intrusions, zones of oxidation, radioactive bodies, water movements, and several other perturbations not easily identified as such. Most common are the hydrological disturbances often characterized by an offset of the geotherm at the interface of the disturbance. Such is the case in boreholes that penetrate aquifers, because they provide a path in which water can circulate between different aquifers.

More subtle to discern is the slow drift of water and heat, simultaneously being transferred within porous sedimentary layers and structural features. The heat exchange between water and rocks creates abnormally low and high temperature gradients in the source and sink regions respectively.

There is also heat exchange in the area above the phreatic level due to rainwater seepage, air circulation, and condensation or evaporation. Near lakes and streams these temperature disturbances are more intense. The kinks in the geo- 
therms of Fig. 6 illustrate disturbances by ground water movements to a depth of 40-70 meters, in an area of about $25 \mathrm{~km}^{2}$ in Butiá (R.G.S.).

Structural and topographic perturbations Geotherms become disturbed by heat refraction along inclined geological structures such as faults and discontinuities, dipping layers of different composition, sills and dikes. The rate of increase of temperature with depth is also influenced by the topographic relief, becoming greater under valleys than under mountain tops. In areas of high relief the underground isothermal surfaces follow the contours of the ground surface, crowding together under valleys, and expanding under hills; the temperature at a given depth below a hilltop generally is lower than at the same depth below an adjacent valley. Moreover, the ground surface is not an isothermal surface but rather shows a decrease of temperature with elevation and sun exposure.

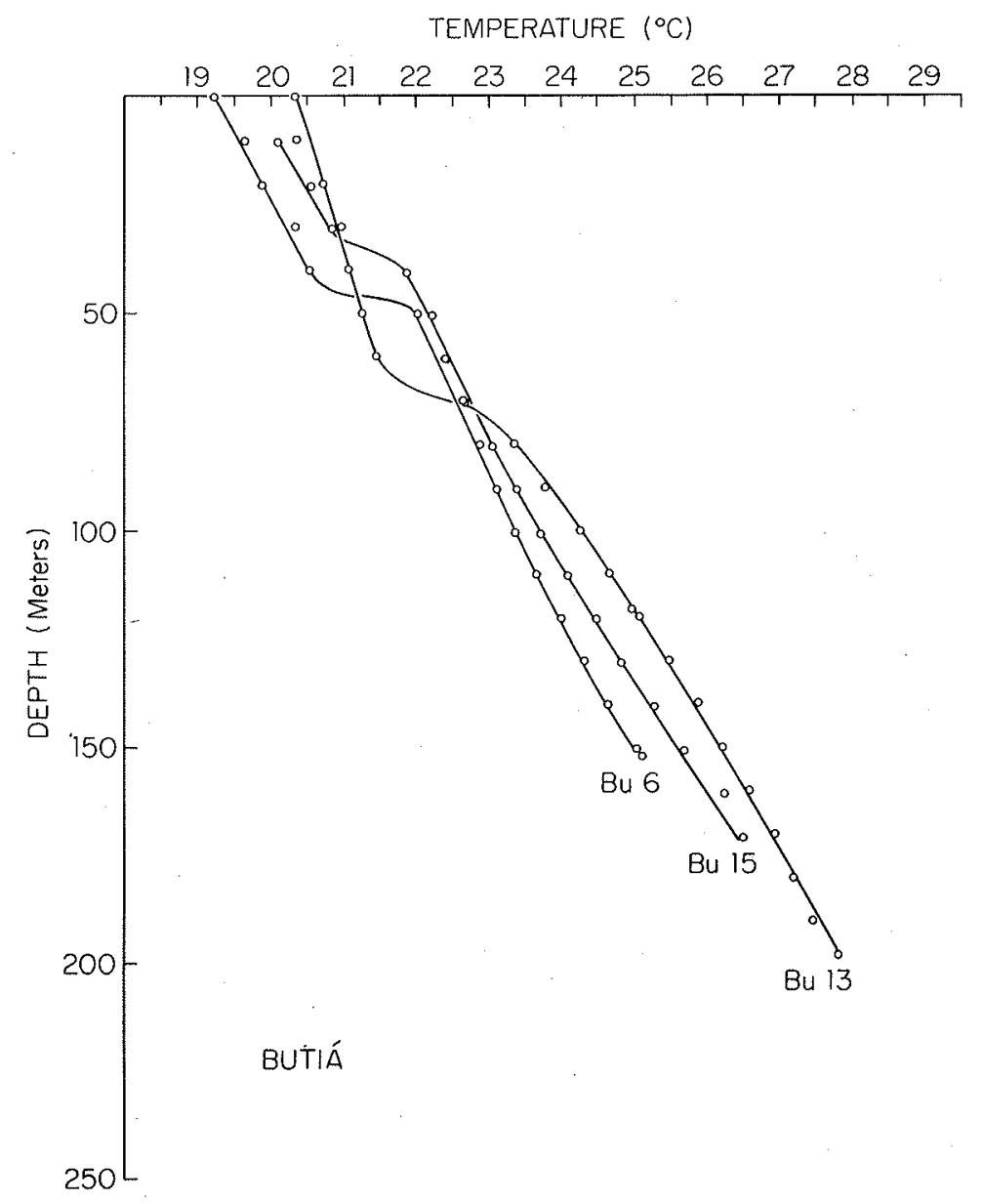

Figure 6 - Effects of water movements on rock temperature, Water circulation through the weathered zone, open fissures and faults, can disturb the characteristic geothermal gradient 
Temperature perturbations due to the drilling process Although most of our measurements were made several weeks after drilling ceased, a few temperature surveys were also made during the drilling, specifically at weekends and occasional shutdowns, or immediately after completion of the borehole. The surrounding rock temperatures become disturbed by the drilling processes mainly by heat exchange with the drilling fluid. The heat produced by friction along the drill rods and by the cutting and grinding action of the drill bit, is absorbed and distributed by the drilling fluid.

Repeated surveys during and after drilling of shallow (not deeper than $300 \mathrm{me}$ ters) diamond drilled boreholes showed a diminishing disturbance from top to bottom in the borehole correlating with the lesser duration of drilling at greater depths. When measurements are consecutively made at several time intervals, the decaying temperature disturbance can be extrapolated to its equilibrium position.

The temperature profile in the left side of Fig. 7 shows the result of repeated thermal surveying in a borehole located in São Paulo. Notice that even though the geotherm shifts towards its equilibrium position during consecutive logging, the same average gradient is obtained regardless of the time elapsed since the end of drilling. Similarly, several other shallow holes drilled in relatively uniform rock material yielded a reasonably reliable gradient, immediately after the end of drilling, later confirmed by repeated thermal logging.

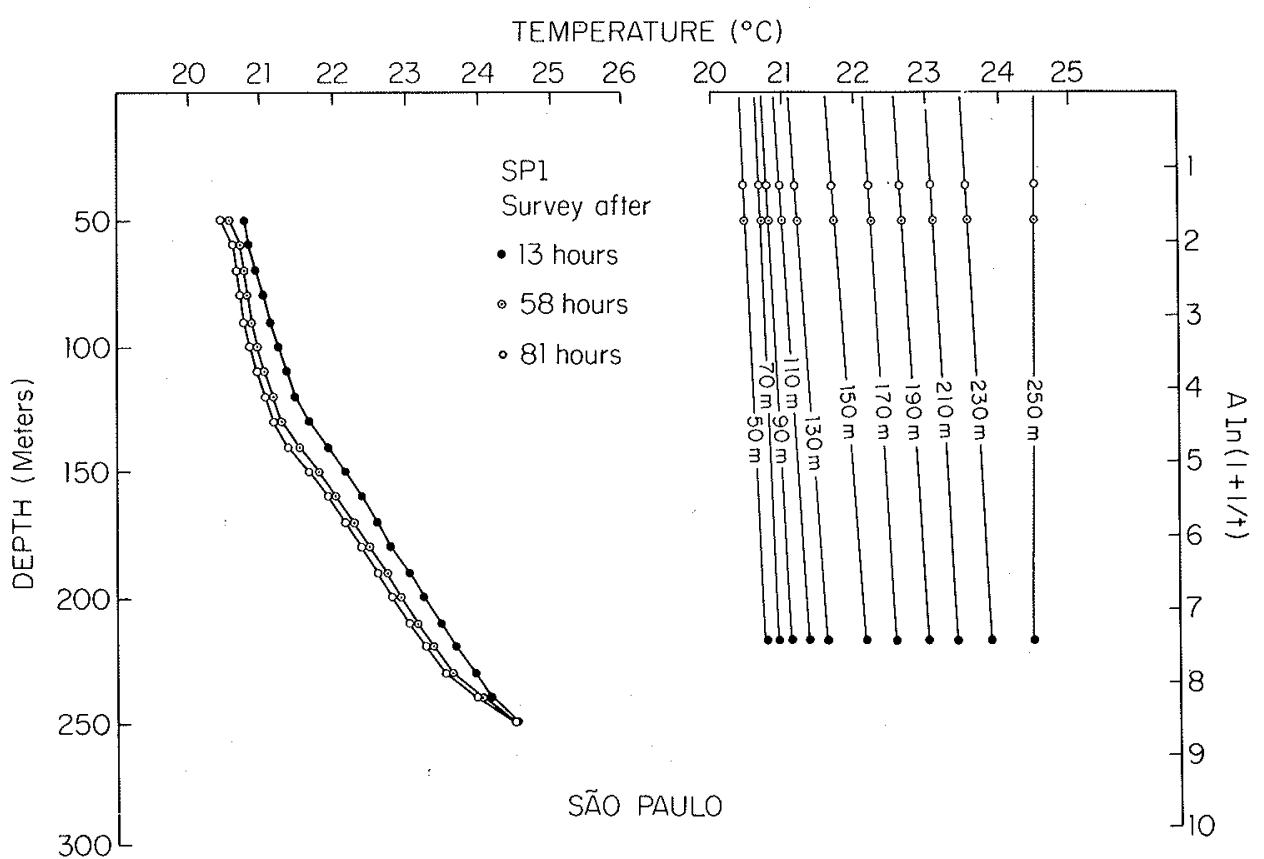

Figure 7 Repeated thermal logging of borehole SP1, at 13,58 and 81 hours after drilling ceased The right diagram shows the extrapolation of the transient disturbed temperature to their equilibrium position on the temperature axis 
In these cases, the disturbed borehole temperature profile decays toward the equilibrium temperature in a logarithmic manner, as suggested by Bullard (1947), and Lachenbruch and Brewer (1959). The linear relationship $T=T \cdot \infty+A \ln (1+$ $1 / t)$ is plotted in the right side of Fig. 7, for three surveying times $t$ after drilling ceased in borehole SP1. The equilibrium temperature $T_{\infty}$ is the intercept on the ordinate.

Progressive deviation from verticality One effect that is commonly interpreted as a thermal perturbation results from deviation of the borehole direction with depth. With no direction control the borehole tends to flatten out as drilling progresses, and a temperature versus depth of the borehole profile shows a progressive lowering of the temperature gradient.

Temperature survey in underground mines Temperature measurements in dry horizontal boreholes were also made at various'levels of the "Mina Grande" gold mine, Nova Lima, M.G., in order to piece together a vertical geothermal gradient. In this mine, the present method of cooling by the circulation of forced air causes heat transfer between air and rock, as the cold surface air penetrates down to 2300 meters below the surface. In the downcast path, the rocks along the main galleries will cool down as the air warms up and in the upcast path the reverse occurs. By selecting sites with no air circulation, that is away from main air paths, we attempted to minimize the temperature disturbances due to the long ventilation history of the mine. The virgin rock temperatures are obtained by making temperature readings at intervals within a horizontal hole (left diagram of Fig. 8), revealing a probable undisturbed temperature of $34.5^{\circ} \mathrm{C}$ at about $100 \mathrm{~m}$ from the tunnel surface. This undisturbed temperature is again $T_{\infty}$ the intercept on the ordinate of the line $T=$ $T_{\infty}+A \ln (1+1 / x)$, where $x$ is the distance away from the tunnel (right diagram of Fig. 8).

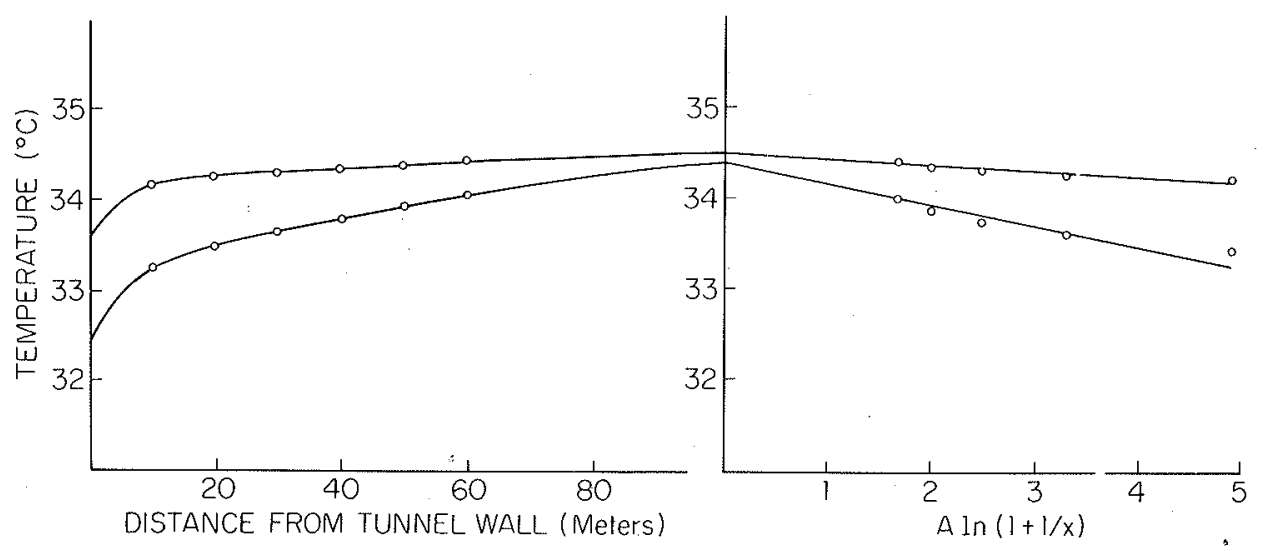

Figure 8 - Extrapolation of temperatures measured in dry horizontal boreholes at level 12 of "Mina Grande" (M.G.), almost 1000 meters below surface. The rocks near tunnels show thermal disturbances due to ventilation

Virgin rock temperature obtained is of approximately $34.5^{\circ} \mathrm{C}$ 
A reliable thermal gradient of about $15^{\circ} \mathrm{C} / \mathrm{km}$ was obtained by fitting a straight line through the plotted virgin rock temperatures, to depths greater than two kilometers.

In Currais Novos (R.G.N.), a surface geothermal pattern was continued below the level of mining by a temperature survey in vertical underground holes within a mine (Fig 9). The advantage of these vertical underground holes is that they yield very deep rock temperatures away from the disturbances caused by the operation of the mine, such as ventilation and water drainage.

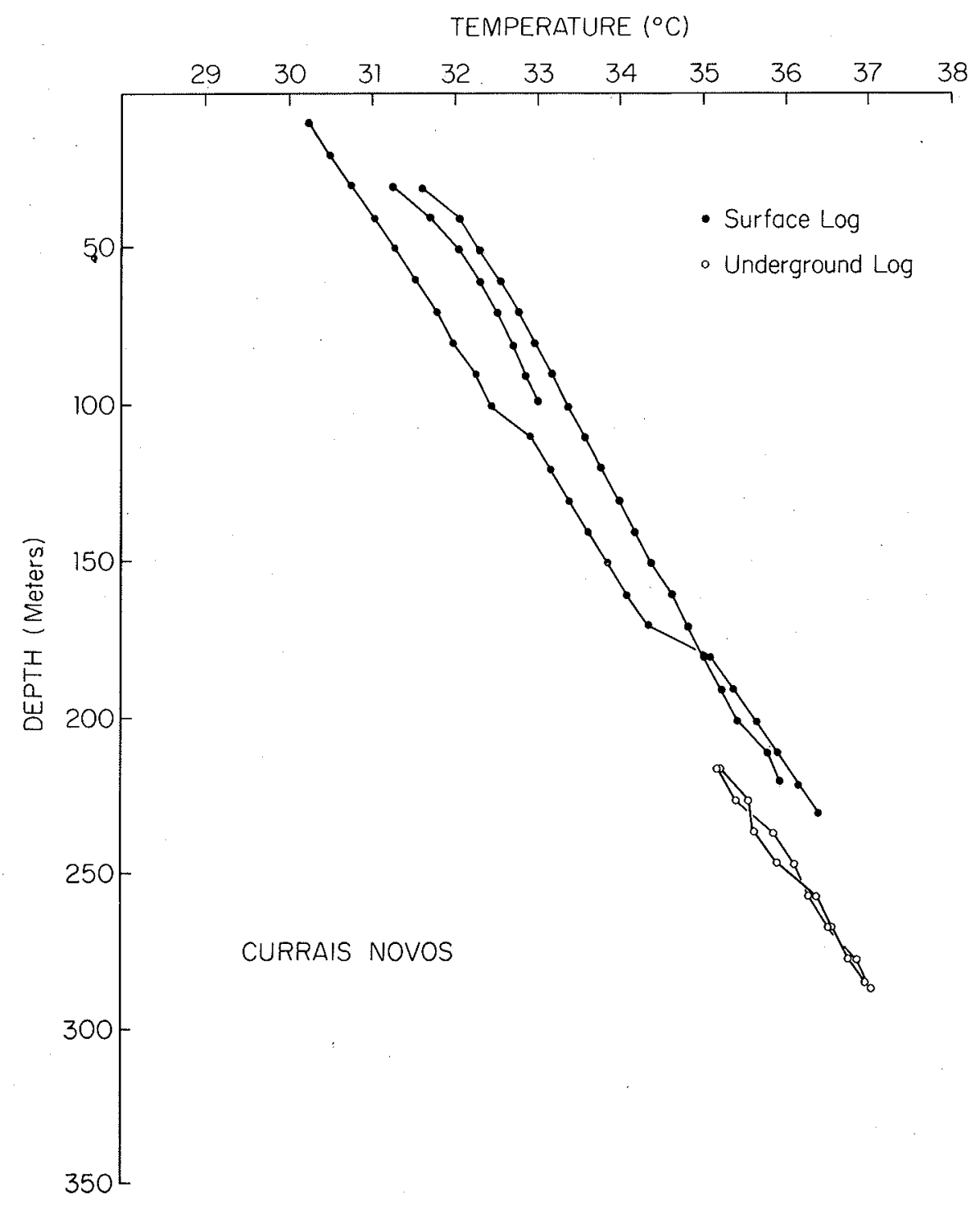

Figure 9 - Thermal gradients in an underground mine at Currais Novos (R.G.N.) 
DISCUSSION Every site listed in Table I has a representative geotherm in Fig. 10, with the exception of Vazante (site n. 9), whose geotherms were virtually coincident with the ones from Morro Agudo (n. 8), and Nova Lima (n. 10), where the profile extends to more than 2000 meters.

Disturbed upper portions are not shown, and the small departures from a straight line observed in several of these geotherms are usually caused by a combination of the disturbances previously described. These disturbances are also responsible for considerable lateral temperature variation $\left(1-2^{\circ} \mathrm{C}\right)$, within small areas of 1 $2 \mathrm{~km}^{2}$ (see Fig. 9).

The extrapolation of the profiles to the surface gives an approximate mean annual surface temperature at the mouth of the borehole. The profiles line up from right to left of the diagram according to their latitude because the mean annual surface temperature decreases with increasing latitude. The average annual air temperature in Brazil varies from $28-30^{\circ} \mathrm{C}$ in the north and northeast, to $16-18^{\circ} \mathrm{C}$ in the south. Since surface temperatures also decrease for increasing altitudes, it explains

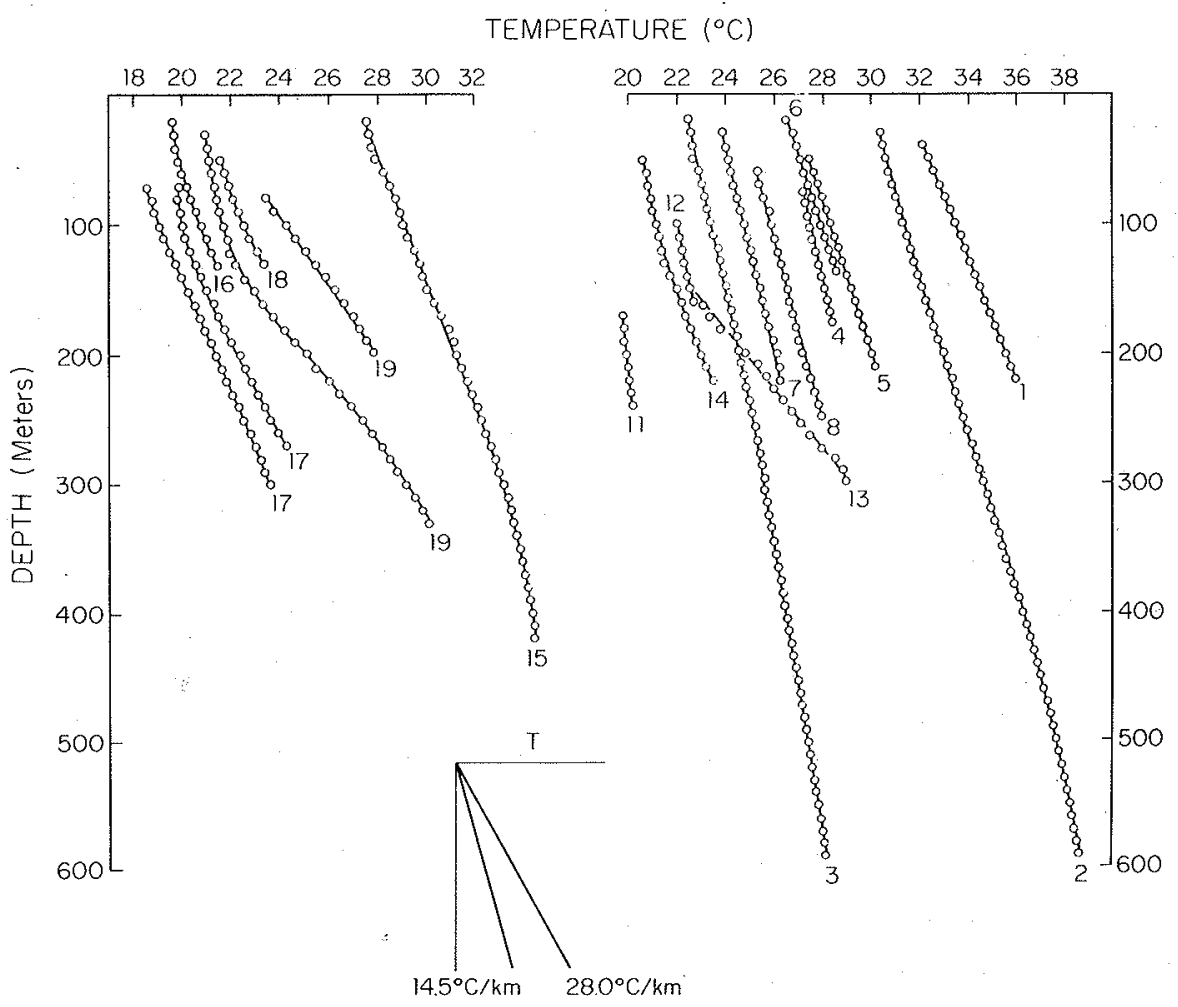

Figure 10 - Representative temperature versus borehole depth profiles of sites located in. Precambrian terrain (right side), Paraná Basin (left side) and Poços de Caldas (n. 13, dashed line). Average geotherm gradient of Precambrian sites $\left(14.5^{\circ} \mathrm{C} / \mathrm{km}\right)$ and of Paraná Ba$\sin \left(28.0^{\circ} \mathrm{C} / \mathrm{km}\right)$ are shown at the bottom 
some of the exceptions to the above variation with latitude such as the position of the representative temperature profile for Jacobina (n. 3). This borehole stands $750 \mathrm{~m}$ above sea level while Caraíba (n. 2) and Cana Brava (n. 5) stand at 455 and 400 meters respectively. The variation of temperature of the land surface with height usually follows the adiabatic lapse rate which is ordinarily in the range 8$10^{\circ} \mathrm{C} / \mathrm{km}$.

For other reasons discussed later, the geotherms from the Paraná basin plot over the geotherms from the Precambrian shield and, therefore, a comprehensible display of the data dictated their separation into two groups: representative geotherms from the Precambrian shield and the one from Poços de Caldas (n. 13, dashed line) are plotted in the right of Fig. 10, while the ones from the Paraná Basin are plotted in the left. An average geothermal gradient from all Precambrian sites $\left(14.5^{\circ} \mathrm{C} / \mathrm{km}\right)$ and one from Paraná Basin sites $\left(28.0^{\circ} \mathrm{C} / \mathrm{km}\right)$, have been inserted in the lower portion of the diagram to facilitate visual comparisons.

The younger Poços de Caldas intrusion into the shield area has notably higher gradients, comparable to the ones from the Paraná basin. On the other hand, the geotherms obtained in the interior of the state of São Paulo (n. 15) show lower gradients than the others from the Paraná basin. However, they have penetrated only the basalt flows; higher gradients might be found below the basalts and Botucatu formation, which are both major aquifers which may be distorting the regional heat flow. Moreover, the extrapolation of these geotherms to the surface show temperatures abnormally higher than the mean annual surface temperature within the state of São Paulo, possibly reflecting a hydrothermal disturbance.

As a general rule, the measurements from shallow boreholes within the Paraná basin should be carefully analyzed for possible hydrological disturbances, because its several intercalated aquifers, basinal structure, and high annual rainfall provide an ideal setting for large scale water movements.

These preliminary results from the Paraná basin indicate an apparent southward increase in temperature gradient from the values found in the state of $S$. Paulo $\left(18-22^{\circ} \mathrm{C} / \mathrm{km}\right)$ to higher values in the state of Rio Grande do Sul $\left(30-42^{\circ} \mathrm{C} / \mathrm{km}\right)$. Several holes exhibiting high gradients are situated along the eastern and southern edges of the basin, and penetrate only the low thermal conductivity shales and siltites of the Permian and Carboniferous formations. Holes in east-central Paraná (Figueira-Curiúva) penetrate the coarser grained siliceous layers of the Devonian Paraná Group, and holes within the state of São Paulo penetrate the Mesozoic Botucatu quartz sandstone, both stratigraphic units with relatively high thermal conductivity.

Thus, it is premature to compare temperature gradients alone, without an analysis of thermal conductivity variations with depth and regionally, and without an estimate of the heat contribution due to radioactive materials, especially in the case of Poços de Caldas.

Previously reported average geothermal gradients for this basin $\left[17^{\circ} \mathrm{C} / \mathrm{km}\right.$ for 39 petroleum boreholes (Meister, 1973) and $16^{\circ} \mathrm{C} / \mathrm{km}$ for 3 petroleum sites (Uyeda and Watanabe, 1970)] are lower than the gradients we report. These earlier measurements are drawn from a wider area and from deeper levels; they average 2200 meters in depth and many of them reach the basement below the basin. Most were calculated on the basis of single bottom-hole temperatures taken shortly after cessation of drilling, 
Such temperatures tend to be lower than the virgin rock temperatures due to the cooling effect of large amounts of drilling fluid used in rotary drilling (Dowdle and Cobb, 1975). The effect of the fluid heat exchange is to warm the top of the hole while cooling the bottom (Jaeger, 1961). Investigations elsewhere have shown the bottom-hole temperatures to be reduced $10-100 \%$ from the virgin rock temperatures (Raymond, 1969; Holmes and Swift, 1970). We believe this drilling disturbance to be a likely source for the apparent discrepancy between the earlier estimates of gradients and those we report here.

We have also grouped the sites listed in Table I into 5 major tectonic regions (Table II). A plot of the average gradient against the tectonic age range of each major region (Fig. 11) shows a decreasing gradient trend from the high Phanerozoic values, to the low Proterozoic results. This suggests a similar correlation of increasing heat flow and decreasing age, as observed elsewhere, as mentioned in the introduction.

Table II - Average temperature gradient of the major tectonic units

\begin{tabular}{lccc}
\hline MAJOR TECTONIC REGIONS & $\begin{array}{c}\text { TECTONIC AGE } \\
\text { RANGE (MY) }\end{array}$ & $\begin{array}{c}\text { NUMBER OF } \\
\text { SITES }\end{array}$ & $\begin{array}{c}\text { AVERAGE GRADIENT AND STANDARD } \\
\text { DEVIATION ( }\end{array}$ \\
\hline $\begin{array}{l}\text { Trans } / \mathrm{km} \text { ) } \\
\text { Espinhaço Folding }\end{array}$ & $2600-1800$ & 3 & $12.2 \pm 4.2$ \\
Braz1liane Folding & $1800-1300$ & 2 & 11.2 \\
$\begin{array}{l}\text { Phanerozoic Sediments } \\
\text { of the Paraná Basin }\end{array}$ & $900-550$ & 8 & $16.1 \pm 4.6$ \\
$\begin{array}{l}\text { Alkaline magmatism } \\
\text { of Poços de Caldas }\end{array}$ & $440-180$ & 5 & $27.9 \pm 6.5$ \\
\hline
\end{tabular}

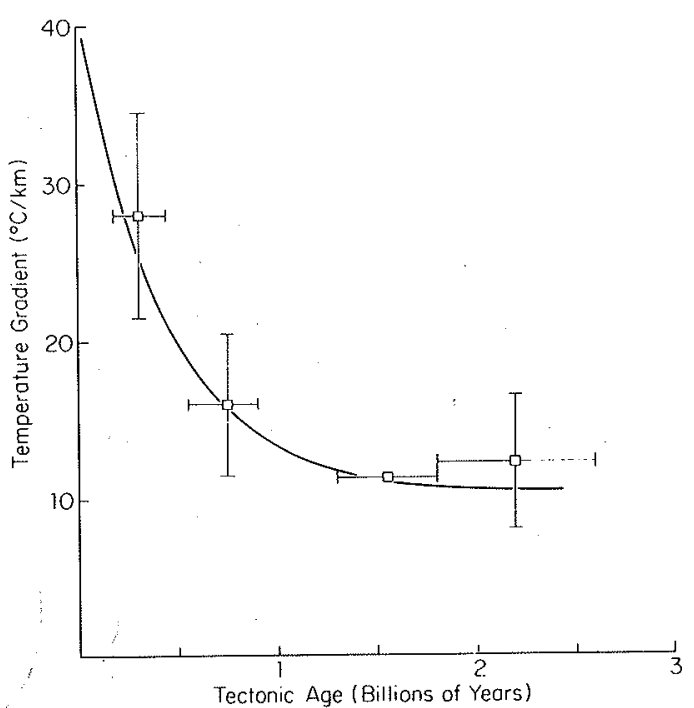

Figure 11 - Average geothermal gradients of each major tectonic unit versus corresponding tectonic age. Vertical bars represent standard deviation, horizontal bars represent age range 
SUMMARY Although we have presented only the preliminary results of the project, and further data and detailed discussion will be forthcoming in the future, there are some conspicuous general features that should be noted. Gradients range from low values found in Jacobina, Bahia $\left(6-10^{\circ} \mathrm{C} / \mathrm{km}\right)$, and Bico de Pedira, M.G. $\left(7-8^{\circ} \mathrm{C} / \mathrm{km}\right)$ to the high values of the area of Butiá and Rio Pardo, R.G.S. (30$42^{\circ} \mathrm{C} / \mathrm{km}$ ) (Table I). When grouped according to tectonic age (Table II), the average gradient spans from $11-12^{\circ} \mathrm{C} / \mathrm{km}$ for the Transamazonic and Espinhaço Folding to the higher $28-30^{\circ} \mathrm{C} / \mathrm{km}$ for the Paleozoic sediments of Paraná Basin and intrusives of Poços de Caldas. These results indicate a consistent correlation between geothermal gradients and tectonic age, which suggests, but does not require, similar correlation of heat flow and age.

The gradients obtained in the Paraná Basin are not only higher than the ones from the shields but also higher than the previously estimated values for the same basin by Uyeda and Watanabe (1970) and Meister (1973). It is yet to be determined if some of these high gradients are associated with water circulation or other thermal anomalies.

Quo Vadis? Determinations of thermal conductivity and radiogenic heat production of the rock samples from the sites where temperature measurements were made, are now being carried out and will be soon available for heat flow analysis. It is our intention to continue the geothermal work in areas of mutual benefit to geophysical research and to industry; mineral exploration, mine development, study of aquifers and hydrothermal sources, and detection of fuel sources (uranium, petroleum and coal).

This project was successful in covering a large portion of the Brazilian territory in a short period of time, but many regions remain unsampled. As deep drilling continues and extends to new areas in the western and northern parts of Brazil, such as Urucum (M.T.), Quatipuru (Pará) and Alto Solimões (Amazonas), we hope to expand the survey with the continuing cooperation of the mining industry and government agencies. It is also hoped that, in the near future, thermal surveying becomes a standard procedure in well logging for mineral and fuel sources exploration, and detection of buried geological structures.

Acknowledgements This work was supported by the Instituto Astronômico e Geofísico da Universidade de S. Paulo (IAG-USP), the Rackham School of Graduate Studies and the Department of Geology and Mineralogy of the University of Michigan, the Conselho Nacional de Pesquisas (CNPq) and the U.S. National Science Foundation.

Our work was greatly facilitated by the active cooperation and assistance provided by the administration of the companies listed below. We are heavily indebted to their members too numerous to mention in this paper: Caraíba Metais, S.A.; Companhia de Pesquisa de Recursos Minerais (CPRM); Depto. de Águas e Energia Elétrica, S.P. (DAAE); Rio Doce Geologia e Mineração S.A. (DOCEGEO); Departamento Nacional de Produção Mineral (DNPM); Indústria e Comércio de Minérios S.A. (ICOMI); Metais de Goiás S.A. (METAGO), Mineração Morro Agudo S.A.; Mineração Morro Velho S.A.; Empresas Nucleares Brasileiras S.A. (NUCLEBRAÂS); S.A. Mineração de Amianto (SAMA); Tungstênio do Brasil Minérios e Metais Ltda.; Unigeo Geologia e Mineração S.A.

We extend our gratitude and acknowledge the help of dedicated members of dozens of other companies, for their interest and assistance in our work. 


\section{REFERENCES}

BECK, A.E, 1976. The use of thermal resistivity logs in stratigraphic correlation: Geophysics, 41 (2): 300-309.

BULLARD, E.C., 1947. The time necessary for a borehole to obtain temperature equilibrium: Royal Astron. Soc. Monthly Notices, Geophys. Supp., 5 (5): 127.

CARVALHO, H.S. and VACQUIER, V., 1977. Method for determining terrestrial heat flow in oil fields: Geophysics, 42 (3): $584-593$

CHAPMAN, D.S. and POLLACK, H.N., 1975. Global heat flow; a new look: Earth Plan. Sci. Lett., 28: 23-32.

DOWDLE, W.L., and COBB, W.M., 1975. Static Formation temperature from well logs - An empirical method: J. Pet. Tech., p. 1326.

HAMZA, V.M. and VERMA, R.K., 1969.. The relationship of heat flow with age of basement rocks: Bull. Volcanol., 33: 123.

HOLMES, C.S. and SWIFT, S.C., 1970. Calculation of circulating mud temperatures: J. Pet. Tech., 22: 670.

JAEGER, J.C., 1961. The effect of the drilling fluid on temperatures measured in bore holes: J. Geophys. Res., 66 (2): 563.

LACHENBRUCH, A.H. and BREWER, M.C., 1959. Dissipation of the temperature effect in drilling a well in Arctic Alaska: U.S. Geol. Surv. Bull., (1083-C): 73-109.

LOVERING, T.S., 1948. Geothermal gradients, recent climatic changes, and rate of sulfide oxidation in the San Manuel District, Arizona: Econ. Geol., 43 (1): 1-20.

MEISTER, E., 1973. Gradientes geotérmicos nas bacias sedimentares Brasileiras: Bol. Técnico da Petrobrás, 16 (4): $221-232$.

POLYAK, B.G. and SMIRNOV, Ya. B., 1968. Relationship between terrestrial heat flow and the tectonics of continents: Geotectonics, 4: 205-213.

RAYMOND, L.R., 1969. Temperature distribution in a circulating drilling fluid: J. Pet. Tech., 21: 333 .

SCLATER, J.G. and FRANCHETEAU, J., 1970. The implications of terrestrial heat flow observations on current tectonic and geochemical models of the crust and upper mantle of the earth: Geophys. J. Roy. Astron. Soc. 20: 509.

Tectonic Map of Brazil, 1:500.000, 1971, D.N.P.M. - Min. Minas e Energia do Brasil.

UYEDA, S. and WATANABE, T., 1970. Preliminary report of terrestrial heat flow study in the South American continent; distribution of geothermal gradients: Tectonophysics, 10: 235-242. 